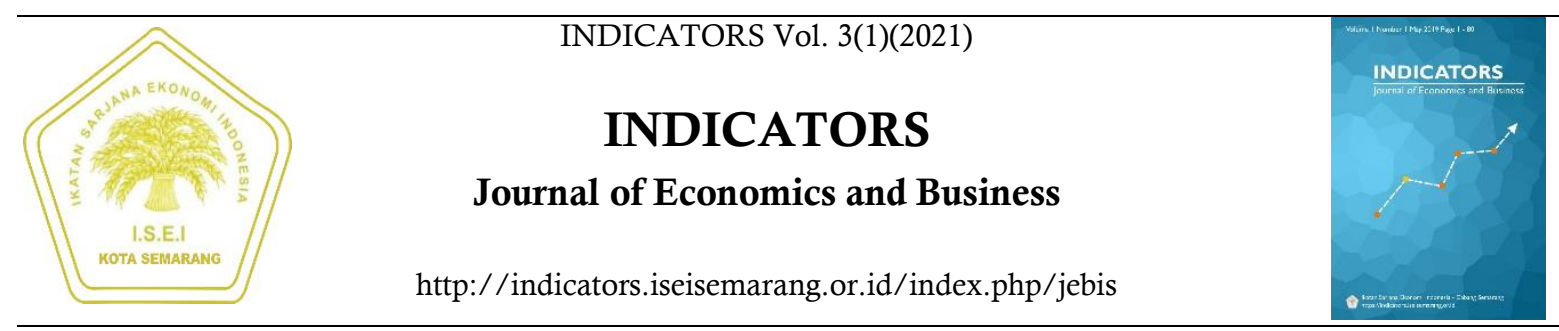

\title{
PENGARUH OWNERSHIP STRUCTURE DAN BOARD GOVERNANCE TERHADAP DIVIDEND PAYOUT RATIO
}

\author{
Eliza Andriani BR Surbakti ${ }^{1}$, Adi Firman Ramadhan ${ }^{2 凶}$
}

${ }^{1,2}$ Departemen Akuntansi Fakultas Ekonomika dan Bisnis Universitas Diponegoro

\begin{tabular}{|c|c|}
\hline Info Artikel & Abstract \\
\hline $\begin{array}{l}\text { Sejarah Artikel: } \\
\text { Diterima Desember } 2020 \\
\text { Disetujui Maret } 2021 \\
\text { Dipublikasikan Mei } 2021\end{array}$ & $\begin{array}{l}\text { This research aims to examine the effect of corporate governance on dividend policy. The ownership structure is } \\
\text { divided into controlling ownership, government-controlled firm, foreign-controlled firm and board governance is } \\
\text { divided to board independent and intensity as independent variables, while dividend payout ratio as dependent } \\
\text { variable. Firm size, growth, return on assets, and leverage are also added as control variable. This research uses } \\
\text { a sample consisting of } 85 \text { banking companies listed on Indonesia Stock Exchange in the period of 2013-2017. }\end{array}$ \\
\hline $\begin{array}{l}\text { Keywords: } \\
\text { Dividend payout ratio, } \\
\text { corporate governance, } \\
\text { ownership structure, board } \\
\text { governance }\end{array}$ & $\begin{array}{l}\text { The purposive sampling method was used in selecting the research sample. Static panel data technique which } \\
\text { was estimated using Tobit regressions are choosen for this research statistic analysis. The result of this research } \\
\text { shows that controlling ownership and government-controlled firm have a positive significant effect on the dividend } \\
\text { payout ratio, but foreign-controlled firm have a negative significant effect on the dividend payout ratio. } \\
\text { Meanwhile, board independent and intensity have a positive but no significant effect on the dividend yield. }\end{array}$ \\
\hline
\end{tabular}

\footnotetext{
${ }^{\triangle}$ Alamat korespondensi: Departemen Akuntansi Fakultas

Ekonomika dan Bisnis Universitas Diponegoro

Jl. Prof. Soedharto SH., Tembalang, Semarang 50239, Phone:

$+622476486851$

Email: afran.ramadhan@gmail.com
}

\section{PENDAHULUAN}

Investor mempunyai salah satu hak yang penting di dalam perusahaan, yaitu dividen (D. \& L. K. P. Setiawan, 2013), Mitton (2004) menyatakan dividen sebagai masalah yang penting untuk investor, terutama pada perusahaan dengan praktik tata kelola yang rendah. Ang et al. (1997) dan Baker et al. (2012) juga menemukan bukti bahwa dividen mempunyai efek yang signifikan terhadap nilai perusahaan, maka dari itu keputusan pembagian dividen sangat penting, khususnya untuk perusahaan di negara berkembang seperti Indonesia. Dalam pembagian dividen oleh perusahaan terdapat perbedaan kepentingan antara prinsipal sebagai pemegang 
saham dan agen sebagai pelaksana dalam manajemen yang disebut dengan konflik agensi, dimana mereka bertindak sesuai dengan kepentingan masing-masing, , ini menggambarkan teori agensi (Jensen \& Meckling, 1976). Untuk itu, kebijakan pembagian dividen yang optimal harus dimiliki oleh perusahaan dalam melakukan pembagian dividen kepada para investor.

Kebijakan pembagian dividen yang dimaksud adalah bagaimana perusahaan harus dapat mempertimbangkan keputusan untuk membagikan laba kepada investor dalam bentuk dividen atau menahan laba perusahaan dan digunakan sebagai penambah modal atau reinvestasi untuk pengembangan perusahaan di masa depan. Baker et al. (2012) berpendapat kebijakan dividen mengarah kepada mekanisme pembayaran yang ditetapkan perusahaan untuk menentukan seberapa banyak dan pola distribusi kas perusahaan kepada pemegang saham dari waktu ke waktu. Untuk menghasilkan sebuah kebijakan, maka dalam perumusan kebijakan ini harus dilakukan dengan hati-hati karena membutuhkan kemampuan untuk memprediksi dan konsistensi (Jabbouri, 2016). Selain itu, kebijakan dividen menjadi salah satu isu keuangan yang fundamental pada perusahaan sebab berhubungan dengan pendanaan perusahaan dan keputusan investasi. Kebijakan dividen di perusahaan (baik swasta maupun BUMN) merupakan masalah yang rumit dan memiliki implikasi keuangan yang besar (fiskal.kemenkeu.go.id).

Dalam penetapan kebijakan dividen perusahaan banyak hal-hal yang mempengaruhi, kepemilikan saham yang terkonsentrasi dalam perusahaan sebagai salah satu faktor yang mempengaruhi (Setiawan $e t$ al., 2016). D. \& L. K. P. Setiawan (2013) berpendapat pengambilan keputusan dengan struktur kepemilikan yang terkonsentrasi pada perusahaan didasarkan pada keputusan dan kebutuhan dari controlling shareholders. Di Indonesia, konsentrasi struktur kepemilikan perusahaan terbagi menjadi kepemilikan saham oleh keluarga, kepemilikan saham oleh pemerintah dan kepemilikan saham oleh pihak asing atau investor asing (Setiawan et al., 2016). Penelitian sebelumnya yang meneliti tentang pengaruh ownership structure terhadap kebijakan pembagian dividen pada perusahaan telah dilakukan di banyak negara baik, negara maju ataupun negara berkembang seperti di Indonesia. Hasil temuan Bradford et al. (2013) menunjukkan bahwa perusahaan dengan kepemilikan yang didominasi oleh kepemilikan pemerintah dan kepemilikan pihak asing berpengaruh positif signifikan atas pembayaran dividen. Berbeda dengan temuan oleh AlNajjar \& Kilincarslan (2017) yang menemukan hubungan negatif signifikan antara kepemilikan saham oleh pihak asing dan kepemilikan oleh pemerintah terhadap kebijakan pembayaran dividen. Kepemilikan oleh investor asing ditemukan berpengaruh tidak signifikan terhadap kebijakan pembayaran dividen oleh perusahaan pada penelitian yang dilakukan oleh Lucyanda, J. (2012).

Pada penelitian sebelumnya yang telah dilakukan, ditemukan bahwa ada kepentingankepentingan yang berbeda antar para pemegang saham, khususnya di perusahaan dengan struktur kepemilikan yang terkonsentrasi di negara berkembang, ini kemudian disebut sebagai konflik agensi (Shleifer \& Vishny, 2002); (Claessens, S. \& Yurtoglu, 2013). Untuk mengatasi konflik tersebut dan agar kepentingan para pemegang saham terlindungi, khususnya untuk pemegang saham minoritas (non-pengendali) maka peranan tata kelola perusahaan yang baik (good corporate governance) sangat dibutuhkan, menempatkan dewan komisaris independen merupakan salah satu cara dalam menjalankan tata kelola perusahaan. Menurut Fama \& Jensen (1983) komisaris independen memainkan peranan krusial untuk mengurangi masalah agensi karena dapat mengurangi konflik keagenan dengan memisahkan aspek manajemen dan kontrol dari proses pengambilan keputusan. Jensen \& Meckling (1976), Shleifer \& Vishny (2002) dan Ghosh (2006) berpendapat bahwa secara khusus kehadiran dewan independen dan frekuensi rapat dewan berperan penting dalam memperkuat fungsi pemantauan sehingga akan mengurangi masalah keagenan. Tetapi disisi lain, komisaris independen dan jumlah pertemuan dewan komisaris mengurangi biaya 
agensi dengan melakukan subsitusi, diasumsikan ketika board independent dan intensity tinggi, pembayaran dividen akan rendah atau sebaliknya (Benjamin \& Zain, 2015).

Pengaruh komisaris independen terhadap kebijakan pembagian dividen menunjukkan hasil yang beragam pada penelitian sebelumnya. Wijayanti (2014) menemukan hasil positif signifikan dalam penelitiannya mengenai pengaruh board independent terhadap kebijakan dividen, hasil ini sejalan dengan penelitian Jiraporn, P. \& Ning (2006) yang menemukan hubungan positif signifikan antara board independent dan pembayaran dividen. Namun, D. \& L. K. P. Setiawan (2013) menemukan bahwa hubungan antara komisaris independen dan pembayaran dividen tidak berpengaruh signifikan di Indonesia. Mehdi et al. (2014) menambahkan bahwa jumlah frekuensi rapat dewan (intensity) berpengaruh positif terhadap kebijakan dividen, sedangkan disisi lain. Benjamin \& Zain (2015) menemukan hubungan negatif signifikan antara intensity dengan pembayaran dividen.

Variabel independen pada penelitian ini yaitu: ownership structure di proxy-kan melalui kepemilikan oleh pengendali (controlling ownership), kepemilikan oleh pemerintah (government ownership), kepemilikan oleh pihak asing (foreign ownership).Komisaris independen (board independent) dan jumlah rapat dewan (intensity) merupakan proxy dari tata kelola dewan (board governance). Variabel kontrol ukuran perusahaan (firm size), pertumbuhan perusahaan (growth), return on assets (ROA), dan leverage digunakan agar terhindar dari adanya bias hasil penelitian (Setiawan et al., 2016).

\section{KERANGKA PEMIKIRAN TEORITIS DAN PERUMUSAN HIPOTESIS}

Dalam penelitian ini, teori agensi digunakan sebagai kerangka teoritis untuk mengkaji pengaruh ownership structure dan board governance atas dividend payouts, karena teori agensi membentuk pilar dalam mekanisme tata kelola perusahaan (Jebaraj et al., 2015). Agency theory ialah konsep yang menggambarkan relasi antara principal dan agent serta permasalahan yang timbul karenanya (agency problems) (Jensen
\& Meckling, 1976). Yang dimaksud principal ialah pihak pemilik saham atau pemberi amanat, sementara agent ialah pihak pengelola atau pelaksana yang diberi amanat oleh principal dalam menjalankan perusahaan (manajemen) (Jensen \& Meckling, 1976). Menurut Anthony \& Govindarajan (2009) terdapat perbedaan keinginan antara principal dan agent karena kedua sisi berusaha untuk memperjuangkan utilitasnya, diasumsikan bahwa para pemegang saham sebagai prinsipal lebih suka dengan return keuangan dari investasinya terhadap perusahaan, sedangkan manajer selaku agen lebih senang pada kenaikan kekayaan perusahaan, free time juga kenikmatankenikmatan lainnya (Anthony \& Govindarajan, 2009).

Jensen \& Meckling (1976) mengungkapkan bahwa manajemen yang cenderung mengejar kepentingan pribadi dalam menjalankan perusahaan akan menimbulkan konflik yang muncul karena ada kontra kepentingan antara pemberi modal (principal) dan pelaksana (agents) yang disebut dengan masalah keagenan (agency problems). Dalam rangka penyelesaian agency problems tersebut, dibutuhkan pengeluaran yang disebut sebagai agency cost dan akan dibebankan kepada kedua belah pihak, principal dan agents (Jensen \& Meckling, 1976). Setiawan et al. (2016) membagi penyebab timbulnya agency cost menjadi 2 tipe, yaitu: konflik antara shareholder sebagai principal dan manager sebagai agent (Tipe I) dan Tipe II adanya konflik di antara majority shareholders selaku pengendali dan minority shareholders selaku pemegang saham non-pengendali. Konflik agensi tipe I terjadi pada perusahaan dengan kepemilikan yang tersebar luas, dan terjadi karena kesenjangan informasi antara manajer sebagai agent dan pemegang saham sebagai principal (Jensen \& Meckling, 1976). Menurut Shleifer \& Vishny (2002), pemegang saham yang tersebar luas tidak memiliki cukup saham untuk memonitor manajer mereka, karena biaya yang dibutuhkan cukup mahal. Pemegang saham besar memegang sejumlah besar saham untuk menanggung biaya pemantauan dan untuk memperoleh laba dari hasil investasi mereka (Shleifer \& Vishny, 2002). Sedangkan, konflik agensi tipe II biasanya terjadi pada perusahaan yang didominasi oleh 
kepemilikan orang dalam (Claessens \& Yurtoglu, 2013). Menurut Shleifer \& Vishny (2002), ketika dominasi kontrol terhadap perusahaan dimiliki oleh pemegang saham,maka mereka memiliki peluang untuk membuat keputusan sesuai selera mereka.

Untuk melindungi hak para pemegang saham minoritas maka mekanisme tata kelola perusahaan dibutuhkan (D. \& L. K. P. Setiawan, 2013), tata kelola perusahaan mempengaruhi kebijakan dividen (Kumar, 2004). Menurut La Porta et al. (2000) ada dua model yang bersaing antara tata kelola perusahaan dan kebijakan dividen: outcome model dan substitution model. Dalam outcome model berpendapat bahwa tata kelola perusahaan yang baik memberikan perlindungan lebih terhadap hak-hak investor, perusahaan dengan tata kelola perusahaan yang baik membayar dividen lebih tinggi dibandingkan perusahaan dengan tata kelola yang buruk, sehingga terdapat hubungan positif antara tata kelola perusahaan dan kebijakan dividen (La Porta et al., 2000). Sedangkan di sisi lain, substitution model berpendapat bahwa perusahaan dengan tata kelola yang buruk akan membayar dividen yang lebih tinggi dalam rangka untuk meningkatkan citra perusahaan di kalangan investor, mereka mencoba untuk menarik investor dengan menggunakan dividen sebagai mekanisme, sehingga La Porta et al. (2000) menyimpulkan hubungan negatif antara tata kelola perusahaan dan kebijakan dividen.

\section{Pengaruh Controlling Ownership terhadap Dividend Payouts}

Pemegang saham pengendali atau pemegang saham terbesar mempunyai peluang untuk mengambil keputusan untuk kepentingan mereka sendiri (Shleifer \& Vishny, 2002). Pada teori agensi yang dikembangkan oleh Jensen \& Meckling (1976), perbedaan kepentingan yang ada pada pemegang saham mayoritas dan minoritas dapat menimbulkan konflik (agency problems). Menurut Johnson et al. (2000) di Asia, pemegang saham pengendali mengambil keuntungan dari struktur piramida atau kelompok bisnis untuk menjaga sumber daya di bawah kendali mereka, seperti mengambil keuntungan dari kerugian pemegang saham minoritas (Xu'nan, 2011). Ini merupakan konflik agensi Tipe II seperti yang diungkapkan oleh
Claessens \& Yurtoglu (2013) yang ditemukan di perusahaan dengan dominasi kepemilikan.

Harada \& Nguyen (2011) mempelajari hubungan antara struktur kepemilikan yang terkonsentrasi dan kebijakan dividen di Jepang, dan menemukan bahwa keberadaan pemegang saham mayoritas sebagai pengendali perusahaan memiliki dampak negatif terhadap pembayaran dividen. Mereka menemukan bahwa pemegang saham pengendali membayar pemegang saham minoritas dengan pembayaran dividen yang rendah. Ini sesuai dengan penelitian Manos et al. (2012)yang menemukan bahwa kelompok bisnis di India lebih memilih untuk tidak membagikan dividennya. Ini menjadi bukti bahwa perusahaan yang sering melakukan transaksi dengan pihak istimewa tertentu membayar dividen yang lebih rendah di Cina (Su et al., 2013).

Maury \& Pajuste (2005) meneliti efek dari beberapa pemegang saham besar terhadap kebijakan pembayaran dividen di Finlandia. Mereka menemukan bagaimana pemegang saham besar mempunyai efek positif terhadap pembayaran dividen. Hal ini sejalan dengan temuan Faccio et al. (2001) bahwa konsentrasi kepemilikan memiliki efek positif pada pembayaran dividen. Penyelidikan yang dilakukan oleh Berzins et al. (2012) dengan mempelajari perusahaan swasta di Norwegia, menemukan bahwa masalah keagenan pada umumnya lebih buruk untuk perusahaan swasta karena mereka tidak memiliki mekanisme pemantauan eksternal (publik), dan mereka juga menemukan bahwa pemegang saham minoritas menerima dividen lebih tinggi ketika konflik keagenan lebih tinggi. Dalam hal ini, perusahaan dengan kepemilikan pengendali memiliki kepentingan yang sama dengan pemegang saham minoritas. Berdasarkan penjelasan yang mendasari sebelumnya, maka dirumuskan hipotesis sebagai berikut.

H1: Controlling Ownership berpengaruh positif terhadap Dividend Payouts.

\section{Pengaruh Government Ownerhsip terhadap Dividend Payouts}

Jumlah perusahaan yang dikendalikan oleh pemerintah yang diperjualbelikan di Bursa Efek Indonesia (BEI) mengalami peningkatan sebesar dua kali lipat selama beberapa periode belakangan di Indonesia (Carney \& Child, 
2013). Berdasarkan teori agensi, perbedaan kepentingan atau tujuan antara agen dan prinsipal akan memicu kesenjangan informasi yang berujung pada konflik antar pemangku kepentingan. Setiawan et al. (2016) berpendapat perusahaan yang dikendalikan oleh pemerintah mempunyai beberapa karakteristik yang berbeda dari perusahaan yang dikendalikan oleh keluarga, salah satunya yaitu perusahaan bertugas untuk membantu pemerintah dalam meningkatkan kesejahteraan masyarakat. Namun terkadang perusahaan ditekan secara politis untuk membayar dividen yang lebih besar kepada pemerintah. He et al. (2012) menganalisis perilaku bank-bank miliki negara di Hong Kong terkait kebijakan dividen mereka dan menemukan bahwa mereka menyalurkan lebih banyak dividen dibandingkan perusahaan swasta. Hal serupa juga ditemukan Bradford et al. (2013) bahwa perusahaan yang dikendalikan oleh pemerintah membayar dividen lebih tinggi dibandingkan dengan perusahaan swasta di Cina. Perusahaan milik negara di Austria juga membagikan dividen lebih tinggi dibandingkan perusahaan swasta (Gugler \& Yurtoglu, 2003). Berdasarkan penjelasan yang mendasari di atas, maka dirumuskan hipotesis sebagai berikut.

H2: Government Ownership berpengaruh positif terhadap Dividend Payouts.

\section{Pengaruh Foreign Ownership terhadap Dividend Payouts}

Carney \& Child (2013) menemukan bahwa jumlah perusahaan yang dikendalikan oleh pihak asing di Indonesia adalah tertinggi kedua dibandingkan dengan negara lain di Asia Timur, menurut Setiawan et al. (2016) telah terjadi peningkatan substansial dalam jumlah perusahaan asing yang ada di Indonesia dalam beberapa tahun terakhir. Oleh karena itu penting untuk menyelidiki pengaruhnya terhadap kebijakan pembayaran dividen. Lam et al. (2012) berpendapat bahwa pemilik asing lebih suka menyimpan dividen dalam perusahaan untuk mendanai investasi perusahaan. Kami berpendapat bahwa terdapat dua kemungkinan bagaimana kepemilikan asing mempengaruhi kebijakan dividen, yaitu: pertama, pemilik asing memilih untuk menerima dividen lebih tinggi, mendorong manajer untuk mengurangi laba ditahan mereka (Joen et al., 2011); dan kedua, pemilik asing cenderung memilih untuk menggunakan pendapatan perusahaan untuk diinvestasikan kembali daripada mendistribusikannya (Lam et al., 2012)

Menurut Jensen \& Meckling (1976) konflik agensi Tipe I timbul antara pemegang saham selaku principal dan manajer selaku agent, dimana konsentrasi kepemilikan yang semakin besar dimiliki oleh pemegang saham sehingga mereka dapat memanfaatkan dividen untuk membatasi kemungkinan manajer dalam melakukan expropriation, sehingga jumlah dividen yang dibayarkan akan semakin tinggi. La Porta et al. (2000) berpendapat organisasi yang di dalamnya dikontrol investor asing semestinya mempunyai proses tata kelola perusahaan yang lebih berdaya guna sehingga mereka akan memimpin untuk membayar dividen lebih tinggi. Hal ini sejalan dengan pendapat Trinugroho et al. (2014) jika perusahaan yang dikendalikan oleh orang asing di negara maju memiliki ciri tata kelola perusahaan yang baik, karena lebih efisien dan dilengkapi teknologi canggih maka mereka membutuhkan standar transparasi dan pengungkapan yang lebih tinggi (Setiawan et al., 2016). Menurut Setiawan et al. (2016) pemilik asing memiliki insetif yang lebih tinggi untuk memantau aktivitas perusahaan demi melindungi investasi mereka. Berdasarkan penjelasan yang mendasari di atas, maka dirumuskan hipotesis sebagai berikut.

\section{H3: Foreign Ownership berpengaruh positif terhadap Dividend Payouts}

\section{Pengaruh Board Independent terhadap Dividend Payouts}

Dewan komisaris independen dalam jajaran dewan komisaris memegang peranan yang penting dalam memonitor manajemen, dengan demikian akan mengurangi biaya agensi dan konflik agensi (Jensen \& Meckling, 1976). Menurut Abdelsalam et al. (2008) dan Farinha (2003) hal ini karena komisaris independen mempunyai wawasan yang luas dan pengalaman serta tidak bergantung kepada manajemen. Keefektifan dalam jajaran dewan ditingkatkan dengan kehadiran dari pihak luar (Ghosh, 2006) sebagai dewan independen akan mempengaruhi kualitas pertimbangan dan keputusan direksi, memberikan arahan strategis 
dan meningkatkan kinerja (Zahra \& Pearce, 1989). Setia-Atmaja (2010) menyatakan bahwa dewan independen memantau kepentingan investor dengan berpartisipasi dalam keputusan dewan, dan berdasarkan pada agensi teori dewan independen dapat bekerja untuk menjamin pemegang saham khususnya pemegang saham minoritas. Wijayanti (2014) menemukan bahwa dewan komisaris independen berpengaruh positif terhadap kebijakan dividen pada perusahaan yang terdaftar di BEI, didukung oleh temuan Ginting (2015) yang menemukan hasil serupa dalam penelitiannya. Dewan independen dan pembayaran dividen memiliki hubungan untuk saling melengkapi, dewan independen mempengaruhi dewan lain untuk membayar dividen yang lebih tinggi, sehingga semakin besar proporsi dewan independen semakin tinggi pula dividen yang dibayarkan (Setia-Atmaja, 2010). Hasil ini sesuai dengan hasil temuan oleh Kowalewski et al. (2008) dan Al-Shabibi \& Ramesh (2011).

Di sisi lain, dividen mempunyai peran untuk mengurangi biaya agensi (Rozeff, 1982). Dengan demikian, perusahaan yang menerapkan corporate governance untuk mengatasi lingkungan akan memilih diantara mekanisme tata kelola alternatif seperti dewan atau dividen (Heraclous, 2001) Berdasarkan pada "model subsitusi", maka akan dihipotesiskan bahwa perusahaan dengan bagian jumlah dewan independen dalam dewan komisaris yang tinggi untuk memperkuat praktik tata kelola dalam organisasi, sehingga akan mengurangi untuk pembayaran dividen yang tinggi (Benjamin \& Zain, 2015). Dalam penelitian sebelumnya yang dilakukan oleh Leng (2008) melaporkan bahwa direksi non-eksekutif dengan menggunakan sampel perusahaan Malaysia berhubungan negatif dengan dividen, diketahui bahwa ambang batas untuk "dewan independen" lebih ketat daripada "direksi non eksekutif" dimana sejalan dengan peraturan dalam Kode Tata Kelola Perusahaan Malaysia. Borokhovich et al. (2005) meneliti hubungan antara dewan independen dan kebijakan dividen selama periode 1992-1999 pada perusahaan-perusahaan di Amerika Serikat, dan hasil temuan mereka menunjukkan hubungan signifikan dan negatif antara dewan independen dan kebijakan dividen. Dewan independen memperkuat kontrol dari pemegang saham, yang akan mengurangi pembayaran dividen (Benjamin \& Zain, 2015). Jika dewan independen merupakan alat pengawasan yang efektif, maka dewan independen dan kebijakan dividen seharusnya saling menggantikan dalam mengawasi masalah agensi (Mehdi et al., 2014). Berdasarkan penjelasan yang mendasari di atas, maka dirumuskan hipotesis sebagai berikut.

\section{H4: Board independent berpengaruh negatif terhadap dividend payouts.}

\section{Pengaruh Intensity terhadap Dividend Payouts}

Pengawasan dewan diharapkan

meningkat melalui frekuensi pertemuan dewan (Knyazeva, 2007), dengan diadakannya sejumlah rapat yang tertata dan terstruktur baik, maka efektifitas dari kinerja dewan dapat berjalan baik, oleh karena itu frekuensi pertemuan dapat menunjukkan kualitas kinerja dewan dalam melaksanakan tugasnya (Laksmana, 2008), sehingga akan mengurangi konflik agensi (Benjamin \& Zain, 2015). Dimana menurut Benjamin \& Zain (2015), frekuensi rapat dewan dan pembayaran dividen sebagai subsitusi dalam mengurangi agency cost. Secara garis besar, studi ini menyarankan dewan yang bertemu lebih sering dikaitkan dengan kemungkinan melaksanakan tugasnya dengan lebih rajin (Lipton \& Lorsch, 1992), kemungkinan lebih sedikit manajemen laba (Zhou \& Chen, 2004), memberikan pemeriksaan dan keseimbangan manajmenen yang efektif (Conger et al., 1998). Laksmana (2008) melaporkan bahwa frekuensi dapat dewan secara positif terkait dengan pengungkapan pada eksekutif praktik kompensasi. Di sisi lain, beberapa penelitian menyarankan dewan untuk mengurangi frekuensi pertemuan merupakan keuntungan untuk perusahaan (Benjamin \& Zain, 2015). Jumlah pertemuan dewan juga ditemukan mempunyai hubungan negatif dengan nilai perusahaan (Vafeas, 1999), yang disebabkan oleh peningkatan aktivitas dewan yang diikuti dengan penurunan harga saham. Jensen (1993) berpendapat bahwa dewan yang berfungsi dengan baik harus lebih jarang bertemu dan menunjukkan lebih sedikit konflik. Literatur yang ada tampaknya menghubungkan mengenai frekuensi rapat dewan yang lebih tinggi atau lebih rendah identik dengan praktik 
tata kelola yang lebih baik atau sebaliknya. Namun, mengingat bukti yang lebih banyak mendukung gagasan bahwa frekuensi rapat dewan yang lebih tinggi diingankan perusahaan, maka penelitian ini mengambil pandangan positif dimana frekuensi rapat dewan yang lebih tinggi diteorikan untuk mewakili praktik tata kelola yang baik dan dividen dianggap memainkan 'peran pengganti' dalam mengurangi konflik keagenan ketika prakti tata kelola rendah. Maka berdasarkan penjelasan yang mendasari di atas, dirumuskan hipotesis sebagai berikut.

\section{H5: Intensity berpengaruh negatif terhadap dividend payouts.}

\section{METODE PENELITIAN}

\section{Variabel Penelitian}

Variabel dependen yang digunakan dalam penelitian ini ialah kebijakan dividen yang kemudian diukur melalui dividend payout ratio (Setiawan et al., 2016). Variabel ini menggambarkan rasio pembayaran dividen atas laba yang dimiliki perusahaan selama satu tahun, menurut Ang et al. (1997) rasio ini menunjukkan bahwa ketika jumlah dividen yang dibagikan semakin besar, maka angka dividend payout ratio akan semakin tinggi.

Variabel independen dalam penelitian ini ialah ownership structure yang diproksikan menjadi empat variabel mengacu pada penelitian Setiawan et al. (2016) dan board governance yang diproksikan menjadi dua variabel mengacu pada penelitian Benjamin \& Zain (2015). Ownership structure dipilih sebagai variabel dependen karena merupakan faktor penentu dalam kebijakan perusahaan (Mehdi et al., 2017), dimana pemegang saham mempengaruhi kekuatan pengambilan keputusan sesuai keinginan mereka (Gugler \& Yurtoglu, 2003); Bistrova et al., 2013). Sedangkan board governance memperoleh peranan penting dalam mengawasi dan mengatur manajemen perusahaan (Mili Mehdi et al., 2014) menurut Fama \& Jensen (1983) kualitas dari performa dewan telah diuji secara luas melalui 3 karakteristik mendasar, yaitu komposisi dewan, struktur dewan, dan intensitas dari aktivitas dewan. Board independent dipilih sebagai proxy atas board governance, sesuai dengan pernyataan Gregory
(2000) bahwa board independent adalah komponen penting dari pengendalian internal dan mekanisme pemantauan perusahaan.

Penelitian ini menggunakan empat variabel kontrol, antara lain growth, firm size, return on assets, dan leverage yang mengacu pada penelitian Setiawan et al. (2016) dan Benjamin \& Zain (2015). Growth atau tingkat pertumbuhan perusahaan diukur nilai pasar dibagi dengan nilai buku ekuitas. Perusahaan dengan growth yang tinggi cenderung mempunyai arus kas bebas yang rendah dan membayar lebih sedikit dividen (Fama \& Jensen, 1983) sehingga ditemukan hubungan negatif antara growth dan dividend (Benjamin \& Zain, 2015). Sedangkan Firm size adalah ukuran perusahaan yang dihitung dengan logaritma natural dari total aset (LNASSETS), firm size digunakan sebagai variabel kontrol karena firm size dilaporkan memiliki hubungan positif dengan dividen (Sulong dan Nor,2008; Bebczuk,2005). Return on asset digunakan sebagai proxy untuk kinerja keuangan (Setiawan et al., 2016). Leverage diukur dengan membagi total liabilitas dan total aset perusahaan (Setiawan et al., 2016), leverage ditemukan berhubungan negatif dengan dividen (Pruit dan Gitman, 1991; Collings et al., 1996) karena leverage dapat mengurangi biaya agensi dalam arus kas bebas (Jensen, 1986; Agrawal dan Jayaraman, 1994).

\section{Populasi dan Sampel}

Populasi yang dipilih untuk penelitian ini ialah perusahaan perbankan yang terdapat di Bursa Efek Indonesia di tahun 2013-2017 dan mempublikasikan laporan tahunannya. Pemilihan sampel dilakukan dengan metode purposive sampling dengan kriteria sebagai berikut:

1. Perusahaan perbankan yang tercatat di BEI pada tahun 2013-2017 secara runtut, kecuali Bank Syariah karena memiliki peraturan yang berbeda dengan bank umum.

2. Perusahaan perbankan yang mempublikasi laporan keuangannya dengan menggunakan mata uang rupiah (Rp), mempublikasikan laporan keuangan yang telah diaudit, dan memiliki data yang dibutuhkan selama periode penelitian (lima tahun) yaitu pada tahun 20132017. 
1. Perusahaan perbankan yang memiliki saldo laba positif dan dapat ditelusuri secara kepemilikan ultimat.

2. Perusahaan perbankan yang membayarkan dividen tunai secara runtut minimal 2 kali selama periode 2013-2017.

3. Perusahaan perbankan yang laporan keuangannya berakhir pada tanggal 31 Desember.

\section{Metode Analisis}

Teknik statistik data panel yang diestimasikan dengan menggunakan regresi Tobit (censored regression model) digunakan untuk menguji hipotesis dalam penelitian ini. Berikut adalah model untuk analisis regresi Tobit yang digunakan dalam penelitian ini:

$$
\begin{aligned}
D P R_{i t}= & \alpha+\beta_{1} U_{i t}+\beta_{2} U^{2}{ }_{i t}+\beta_{3} \text { GOES }_{i t}+ \\
& \beta_{4} \text { FORs }_{i t}+\beta_{5} \text { BOARDIND }_{i t}+ \\
& \beta_{6} \text { INTENSITY }_{i t}+\beta_{7} \text { FS }_{i t}+ \\
& \beta_{8} \text { GROWTH Hit }_{i t}+\beta_{9} \text { ROA }_{i t}+ \\
& \beta_{10} \text { LEVERAGE }_{i t}
\end{aligned}
$$

Keterangan:

$\begin{array}{ll}\text { DPR } & \text { dividend payout } \\ & \text { (dividend per share } \\ & \text { dibagi earning per share) } \\ & =\text { controlling ownership } \\ & \text { (persentase dari hak } \\ & \text { kontrol) } \\ & =\text { kuadrat dari } \\ U_{2} & \text { controlling ownership } \\ & =\text { government-controlled } \\ \text { GOEs } & \text { firms (variabel dummy, } \\ & 1 \text { jika pemerintah } \\ & \text { mempunyai } 20 \text { persen } \\ & \text { atau lebih hak kontrol) } \\ & =\text { foreign-controlled firms } \\ & \text { ( variabel dummy, } 1 \\ & \text { jika pihak asing } \\ & \text { mempunyai } 20 \text { persen } \\ & \text { atau lebih hak kontrol) } \\ & =\text { board independent } \\ & \text { (proporsi dewan } \\ & \text { independen dalam } \\ & \text { perusahaan, dewan } \\ \text { BOARD } & \text { independen dibagi } \\ & \text { total dewan komisaris) } \\ & =\text { intensity (jumlah } \\ & \text { pertemuan internal } \\ & \text { dewan komisaris) }\end{array}$

$\begin{array}{ll}\text { FS } & \text { firm size (logaritma } \\ & \text { natural dari total aset } \\ \text { perusahaan) } & \\ \text { GROWTH } & \text { growth (rasio nilai } \\ \text { pasar dibagi dengan } & \text { nilai buku) } \\ & =\text { return on assets (rasio } \\ \text { ROA } & \text { laba bersih dibagi } \\ & \text { dengan total aset) } \\ & =\text { leverage (rasio total } \\ \text { LEVERAG dibagi dengan } \\ \text { total aset) }\end{array}$

\section{HASIL DAN PEMBAHASAN \\ Deskripsi Sampel Penelitian}

Data sekunder yang dipakai dalam penelitian ini adalah data yang diperoleh dari BEI. Perusahaan sektor perbankan yang terdaftar di BEI selama lima tahun (2013-2017) digunakan sebagai populasi pada penelitian ini. Sampel dihimpun dengan menggunakan metode purposive sampling. JumIah perusahaan sektor perbankan yang telah terdaftar di BEI selama tahun 2013-2017 adalah sebanyak 42 perusahaan. Sedangkan perusahaan yang mencukupi sebagai kriteria sampel penelitian adalah sebanyak 17 perusahaan. Dengan demikian jumlah sampel yang digunakan adalah 17 perusahaan sektor perbankan selama tahun 2013-2017, sehingga menghasilkan 85 data yang dijadikan pengamatan dalam penelitian. Untuk lebih jelas, kriteria pengambilan sampel dapat dilihat pada tabel 1 sebagai berikut:

Tabel 1. Kriteria Pengambilan Sampel

\begin{tabular}{lll}
\hline No. & Keterangan & Jumlah \\
\hline 1 & Perusahaan perbankan & 42 \\
& yang melaporkan \\
& laporan tahunan dan \\
& laporan keuangannya \\
& secara konsisten di \\
& website BEI berturut- \\
& turut pada tahun 2013 \\
& sampai 2017 dan dapat \\
& ditelusuri secara \\
& kepemilikan ultimat. \\
\hline 2 & Perusahaan yang 7 \\
& dikeluarkan karena \\
& baru listing pada tahun \\
& 2013 atau setelah tahun \\
& 2013 di BEI.
\end{tabular}




\begin{tabular}{lll}
\hline 3 & \multicolumn{1}{l}{$\begin{array}{l}\text { Perusahaan yang tidak } \\
\text { membayar dividen } \\
\text { minimal 2 kali berturut- } \\
\text { turut selama periode } \\
\text { penelitian }\end{array}$} \\
\hline 4 & $\begin{array}{l}\text { Perusahaan dengan } \\
\text { saldo laba negatif }\end{array}$ & 0 \\
\hline 4 & Total Sampel Penelitian & 17 \\
\hline 5 & Tahun Observasi & 5 \\
\hline $\mathbf{6}$ & $\begin{array}{l}\text { Total Data } \\
\text { Pengamatan }\end{array}$ & $\mathbf{8 5}$ \\
\hline
\end{tabular}

\section{Analisis Statistik Deskriptif}

Tabel 2 dan 3 menyajikan deskriptif statistik untuk variabel-variabel dalam penelitian ini. Pada tabel 2, nilai rata-rata untuk variabel pembayaran dividen (DPR) adalah 0,2946 (29,46 persen) hasil ini lebih tinggi dibandingkan dengan penelitian sebelumnya yang dilakukan di Cina oleh Wei et al., (2011) nilai rata-rata yang ditemukan sebesar 22,49 persen dan di Indonesia penelitian serupa dilakukan pada tahun 2006-2012 ditemukan nilai rata-rata dividend payout sebesar 23,86 persen (Setiawan et al., 2016). Ini menunjukkan bahwa seiring berjalannya waktu, perusahaan di Indonesia semakin stabil dan mampu menghasilkan profit bagi investor. Nilai maksimum DPR sebesar 0,747 terdapat pada perusahaan Bank Pembangunan Daerah Jabar dan Banten Tbk pada tahun 2016, sedangkan nilai minimum DPR adalah 0,00 dengan standar deviasi sebesar 0,195.

Nilai rata-rata controlling ownership di Indonesia adalah sebesar 0,583. Angka tersebut menunjukkan bahawa kepemilikan perusahaan di Indonesia sebagian besar terkonsentrasi, hasil ini hampir sama dengan temuan Truong dan Heaney (2007) yang menemukan kepemilikan pengendali di Indonesia sebesar 52,85 persen. Nilai maksimum variabel UO adalah sebesar 0,894 terdapat pada Bank Mestika (BBMD) dimana pemegang saham pengendali pada perusahaan dipegang oleh PT Mestika Benua Mas dengan kepemilikan sebesar 89,44 persen. Nilai minimum variabel UO sebesar 0,224 terdapat pada Bank Bukopin di tahun 2014 dimana pemegang saham pengendali adalah PT Bosowa Corporindo, standar deviasi untuk variabel UO adalah sebesar 0,169 .

Pada Tabel 3 menunjukkan bawah kepemilikan terbesar perusahaan perbankan di Indonesia dikuasai oleh pihak asing, nilai ratarata dari foreign-controlled ownership (FORS) adalah 0,5529 . Terdapat 9 perusahaan dari 17 perusahaan yang diobservasi dimana investor asing mempunyai saham sebesar 20 persen atau lebih pada perusahaan. Sementara pemerintah memegang peranan yang tidak terlalu besar, nilai rata-rata dari variabel government-controlled ownership (GOES) sebesar 0,235 temuan ini lebih tinggi apabila dibandingkan dengan penelitian sebelumnya oleh Setiawan et al. (2016) sebesar 10,65 persen. Ditemukan dari 17 perusahaan yang diobservasi terdapat 4 perusahaan dimana pemerintah Indonesia memegang sebesar $20 \%$ atau lebih saham, antara lain: Bank Negara Indonesia (BBNI), Bank Rakyat Indonesia (BBRI), Bank Tabungan Negara (BTN) dan Bank Mandiri (BMRI).

Tabel 2. Statistik Desktiptif untuk Continuous Variables

\begin{tabular}{lrrrrrrrr}
\hline & DPR & UO & UO2 & BOARD & INTENSITY & FS & GROWTH & ROA \\
\hline Mean & 0.294 & 0.583 & 0.369 & 0.591 & 18.87 & 31.540 & 1.766 & 0.016 \\
Maximum & 0.747 & 0.894 & 0.800 & 0.8000 & 64.00 & 34.658 & 6.496 & 0.092 \\
Minimum & 0.000 & 0.224 & 0.050 & 0.500 & 4.00 & 27.710 & 0.202 & 0.001 \\
Std. Dev. & 0.195 & 0.169 & 0.199 & 0.091 & 1.915 & 1.079 & 0.011 & 0.045 \\
Observation & 85 & 85 & 85 & 85 & 85 & 85 & 85 & 85 \\
\hline
\end{tabular}

Sumber: Output Eviews, data sekunder yang diolah, 2019

Tabel 3. Statistik Desktiptif untuk Dummy Variables 


\begin{tabular}{lll}
\hline & GOES & FORS \\
\hline Mean & 0.235 & 0.552 \\
Maximum & 1.000 & 1.000 \\
Minimum & 0.000 & 0.000 \\
Std. Dev. & 0.426 & 0.500 \\
Observations & 85 & 85
\end{tabular}

Sumber: Output Eviews, data sekunder yang diolah, 2019

BOARD memiliki nilai rata-rata 0,591 hasil ini cukup tinggi dibandingkan dengan temuan sebelumnya sebesar 38,5 persen oleh Rahman dan Ali (2006), 0,3828 oleh Akhtaruddin et al. (2009), dan sedikit lebih tinggi hasil yang ditemukan oleh Jebaraj et al. (2015) sebesar 0,428. Nilai maksimum variabel BOARD sebesar 0,800 terdapat pada Bank Pembangunan Daerah Jawa Barat dan Banten (BJBR) dimana dari 5 dewan komisaris terdapat 4 komisaris independen pada tahun 2017 dan juga Bank Pembangunan Daerah Jawa Timur (BJTM) untuk tahun 2016 dan 2017 terdapat 4 komisaris independen dari total 5 dewan komisaris. Nilai minimum variabel BOARD adalah 0,500 dan standar deviasi sebesar 0,091. Hasil ini menunjukkan bahwa mayoritas dari anggota dewan komisaris dari perusahaan sampel adalah anggota independen dan perusahaan-perusahaan perbankan di Indonesia telah sesuai dengan ketentuan yang berlaku bahwa jumlah minimal komisaris independen sebesar $50 \%$ dari total keseluruhan dewan komisaris (POJK Nomor 55/POJK.03/2016).

INTENSITY memiliki nilai rata-rata sebesar 18,88 persen yang menunjukkan indikasi bahwa anggota dewan komisaris melakukan rapat atau pertemuan rata-rata sebanyak 18,88 kali selama satu tahun, temuan ini cukup tinggi dibandingkan dengan penelitian sebelumnya yang dilakukan oleh Yatim et al. (2006) dan Jebaraj et al. (2015) sebanyak 5.56 kali selama satu tahun. Nilai maksimum variabel INTENSITY sebesar 64,00 terdapat pada perusahaan Bank Pembangunan Daerah Jawa Barat dan Banten (BJBR) yang mengadakan rapat dewan komisaris sebanyak 64 kali selama tahun 2014. Nilai minimum variabel INTENSITY ialah sebesar 4,00 terdapat pada perusahaan Bank
Mestika Dharma (BBMD) pada tahun 2013 dan 2014, Bank Maspion Indonesia (BMAS) pada tahun 2013 dan 2014, Bank Mayapada Internasional (MAYA) pada tahun 2013, dan Bank Mega (MEGA) pada tahun 2013 dan 2015. Hasil ini menunjukkan bahwa perusahaan perbankan di Indonesia telah melaksanakan POJK No.55/POJK.03/2016 bahwa rapat dewan komisaris minimal dilaksanakan 4 kali dalam setahun.

\section{Pembahasan Hasil PenelitianB}

erdasarkan hasil regresi yang dilakukan, ditemukan bahwa variabel independen yaitu UO dinyatakan berpengaruh positif terhadap variabel dependen yaitu DPR dengan probabilitas sebesar 0,002 dimana nilai prob. $<0,05$. Maka dapat disimpulkan bahwa semakin tinggi persentase kepemilikan oleh pengendali (controlling ownership) maka semakin besar dividen yang dibayarkan oleh perusahaan. Penelitian ini juga memeriksa hubungan non-monotonik struktur kepemilikan terhadap pembayaran dividen. Seperti terlihat dalam hasil uji $\mathrm{z}$ yang telah dilakukan terdapat hubungan negatif antara nilai kuadrat pemegang saham pengendali terhadap pembayaran dividen, yang berarti terdapat hubungan non-monotonik antara konsentrasi kepemilikan perusahaan terhadap pembayaran dividen. Berdasarkan hasil tersebut, maka dapat disimpulkan H1 diterima. Pada tabel 4 juga ditemukan hasil positif berpengaruh variabel GOEs terhadap DPR, berarti pihak pemerintah sebagai pemegang saham membayar lebih tinggi dividen kepada pemegang saham, maka disimpulkan bahwa H2 diterima. Untuk variabel FORs ditemukan hubungan berpengaruh negatif, dimana pihak asing sebagai pemegang saham membayar lebih sedikit dividen kepada para pemegang saham,maka dapat disimpulkan bahwa $\mathrm{H} 3$ ditolak. Sedangkan hasil untuk variabel BOARD dan INTENSITY menunjukkan hubungan dengan arah positif, tetapi tidak memiliki pengaruh yang signifikan terhadap variabel DPR, sehingga disimpulkan bahwa $\mathrm{H} 4$ dan H5 ditolak.

Pada tabel 4 juga terdapat hasil yang menunjukkan pengaruh dari variabel kontrol yang digunakan dalam penelitian ini terhadap variabel dependen. Variabel FS, GROWTH, 
dan ROA dinyatakan tidak berpengaruh signifikan terhadap variabel dependen DPR. Berarti, ukuran perusahaan, pertumbuhan perusahaan dan tingkat pengembalian aset tidak memiliki pengaruh terhadap pembayaran dividen oleh perusahaan. Sementara itu, untuk variabel kontrol LEVERAGE memiliki pengaruh negatif terhadap pembayaran dividen, dapat disimpulkan bahwa ketika tingkat leverage perusahaan semakin tinggi, maka jumlah dividen yang dibagikan kepada pemegang saham semakin kecil. Hasil uji hipotesis dapat dilihat pada tabel 4.

Tabel 4. Hasil Uji Z

\begin{tabular}{|c|c|c|c|c|}
\hline $\begin{array}{l}\text { Varia } \\
\text { ble }\end{array}$ & Coefficient & $\begin{array}{l}\text { z- } \\
\text { Statistic }\end{array}$ & Prob. & Hasil \\
\hline $\mathrm{UO}$ & 2.266 & 3.005 & 0.002 & $\begin{array}{l}\text { Berpengar } \\
\text { uh positif }\end{array}$ \\
\hline $\mathrm{UO} 2$ & -2.351 & -3.668 & 0.000 & $\begin{array}{l}\text { Berpengar } \\
\text { uh negatif }\end{array}$ \\
\hline $\begin{array}{l}\text { GOE } \\
S\end{array}$ & 0.159 & 2.497 & 0.012 & $\begin{array}{l}\text { Berpengar } \\
\text { uh positif }\end{array}$ \\
\hline $\begin{array}{l}\text { FOR } \\
\mathrm{S}\end{array}$ & -0.197 & -4.128 & 0.000 & $\begin{array}{l}\text { Berpengar } \\
\text { uh negatif }\end{array}$ \\
\hline $\begin{array}{l}\mathrm{BOA} \\
\mathrm{RD}\end{array}$ & 0.065 & 0.290 & 0.771 & $\begin{array}{l}\text { Tidak } \\
\text { berpengar } \\
\text { uh } \\
\text { signifikan }\end{array}$ \\
\hline $\begin{array}{l}\text { INT } \\
\text { ENSI } \\
\text { TY }\end{array}$ & -0.000 & -0.080 & 0.935 & $\begin{array}{l}\text { Tidak } \\
\text { berpengar } \\
\text { uh } \\
\text { signifikan }\end{array}$ \\
\hline FS & -0.014 & $-1,201$ & 0.229 & $\begin{array}{l}\text { Tidak } \\
\text { berpengar } \\
\text { uh } \\
\text { signifikan }\end{array}$ \\
\hline $\begin{array}{l}\text { GRO } \\
\text { WT } \\
\mathrm{H}\end{array}$ & 0.008 & 0.396 & 0.692 & $\begin{array}{l}\text { Tidak } \\
\text { berpengar } \\
\text { uh } \\
\text { signifikan }\end{array}$ \\
\hline ROA & -1.101 & $-0,539$ & 0.589 & $\begin{array}{l}\text { Tidak } \\
\text { berpengar } \\
\text { uh } \\
\text { signifikan }\end{array}$ \\
\hline $\begin{array}{l}\text { LEV } \\
\text { ERA } \\
\text { GE }\end{array}$ & -2.001 & -3.441 & 0.000 & $\begin{array}{l}\text { Berpengar } \\
\text { uh negatif }\end{array}$ \\
\hline $\mathrm{C}$ & 1.647 & 2.282 & 0.022 & \\
\hline
\end{tabular}

\section{SIMPULAN}

Berdasarkan hasil uji hipotesis yang dilakukan maka ditemukan bahwa controlling ownership berpengaruh positif signifikan terhadap dividend payouts. Dapat disimpulkan bahwa perusahaan dengan persentase kepemilikan pengendali yang tinggi akan membayar dividen yang lebih tinggi pada perusahaan perbankan di Indonesia, hasil ini konsisten dengan penelitian-penelitian sebelumnya yang menemukan hasil serupa. Lalu, government ownership berpengaruh positif signifikan terhadap dividend payouts. Maka dapat disimpulkan bahwa semakin tinggi kepemilikan pemerintah dalam perusahaan maka semakin besar dividen yang dibagikan oleh perusahaan perbankan di Indonesia. Foreign ownership berpengaruh negatif signifikan terhadap dividend payouts. Maka ditarik kesimpulan bahwa perusahaan dengan kepemilikan asing yang tinggi akan membayar lebih sedikit dividen dalam konteks perusahaan perbankan di Indonesia. Berdasarkan hasil uji hipotesis yang dilakukan maka ditemukan bahwa board independent berpengaruh positif tidak signifikan terhadap dividend payouts. Jumlah komisaris independen yang tidak berpengaruh signifikan terhadap proporsi dividen yang dibagikan, dapat dikarenakan komisaris independen tidak memiliki peranan langsung dalam pembuatan keputusan, khususnya keputusan pembagian laba perusahaan. Berdasarkan hasil uji hipotesis yang dilakukan maka ditemukan bahwa intensity berpengaruh positif tidak signifikan terhadap dividend payout. Disimpulkan bahwa frekuensi pertemuan oleh dewan komisaris tidak berpengaruh besar dalam banyaknya dividen yang dibagikan perusahaan perbankan di Indonesia.

Penelitian ini memiliki beberapa keterbatasan, antara lain: terbatasnya data yang diperoleh karena banyak perusahaan perbankan yang tidak membagikan dividen berturut-turut selama periode penelitian, proksi yang digunakan untuk ownership structure dan board governance masih terbatas pada controlling ownership, government ownership, foreign ownership, board independent dan intensity. 
Dan penggunaan regresi Tobit yang masih sangat jarang digunakan di Indonesia untuk variabel dependen dengan data terbatas (censured data) seperti pembayaran dividen.

\section{DAFTAR PUSTAKA}

Abdelsalam, O., El-Masry, A. \& Elsegini, S. (2008). "Board composition, ownership structure and dividend policies in an emerging market: further evidence from CASE 50." Managerial Finance, 34, 953964.

Abdul, H. (2003). Analisis Investasi (Pertama). Salemba Empat.

Abor, J., \& Fiador, V. (2013). Does corporate governance explain dividend policy in Sub-Saharan Africa? International Journal of Law and Management, 55(3), 201-225. https://doi.org/10.1108/175424313113 27637

Agus Sartono R. (2001). Manajemen Keuangan Teori dan Aplikasi (Empat). Yogyakarta: BPFE.

Al-Najjar, B., \& Kilincarslan, E. (2017). Corporate dividend decisions and dividend smoothing. International Journal of Managerial Finance, 13(3), 304-331. https://doi.org/10.1108/ijmf-10-20160191

Al Shabibi, B. K. and R. G. (2011). "An Empirical Study on the Determinants of Dividend Policy in the UK." Journal of Finance and Economic Issue, 80, 14502887.

Ang, J.S., Fatemi, A. and Tourani-Rad, A. (1997). "'Capital structure and dividend policies of Indonesian firms." PacificBasin Finance Journal, 5, 87-103.

Anthony, R. N. dan V. G. (2009). Sistem Pengendalian Manajemen.

Aribowo, T. (2007). Analisis Reaksi Investor terhadap Pengumuman Pembayaran Dividen. Universitas Islam Indonesia.

Baker, H.K. and Powell, G. E. (2012). "'Dividend policy in Indonesia: survey evidence from executives." Journal of Asia Business Studies, 6, 79-92.

Bekaert, G., \& Harvey, Cambell, R. (2010). Foreign Speculators and Emerging
Equity Markets. The Journal of Financeournal, 55(2), 565-613.

Benjamin, S. J., \& Zain, M. M. (2015). Corporate governance and dividends payout: are they substitutes or complementary? https://doi.org/10.1108/JABS-08-20140062

Berzins, J., Bøhren, Ø., \& Stacescu, B. (2012). Stockholder Conflicts and Dividend Payout. SSRN Electronic Journal, (5). https://doi.org/10.2139/ssrn.2146944

Bokpin, G. A. (2011). Ownership structure, corporate governance and dividend performance on the Ghana Stock Exchange. Journal of Applied Accounting Research, 12(1), 61-73. https://doi.org/10.1108/096754211111 30612

Borokhovich, K., Brunarski, K., Harman, Y. and Kehr, J. (2005). "Dividends, Corporate Monitors and Agency Costs." The Financial Review, 40, 37-65.

Bradford, W., Chen, C. and Zhu, S. (2013). "Cash dividend policy, corporate pyramids, and ownership structure: evidence from China." International Review of Economics \& Finance, 27, 445464.

Brigham, E. F. dan J. F. H. (2001). Manajemen Keuangan. Jakarta: Salemba Empat.

Capulong, M., Virginita, D.E., Webb, D. and Zhuang, J. (2001). "Corporate Governance and Finance in East Asia: A Study of Indonesia, Republic of Korea, Malaysia, Philippines, and Thailand Volume One (A Consolidated Report), Asian Development Bank, Manila." Journal of Finance.

Carney,R.W.andChild, T. B. (2013). "Changes to the ownership and control of East Asian corporations between 1996 and 2008: the primacy of politics." Journal of Financial Economics, 107, 494-513.

Claessens, S., Djankov, S. and Lang, L. H. . (2000). 'The separation of ownership and control in East Asian corporations". Emerging Markets Review, 15, 1-33.

Claessens, S. and Yurtoglu, B. B. (2013). "Corporate governance in emerging 
markets: a survey." Emerging Markets Review, 0, 1-33.

Conger, J.A., Finegold, D. and Lawler, E. (1998). "Appraising board performance". Harvard Business Review, 76, 136-148.

Effendi, M. A. (2009). "The Power of Corporate Governance: Teori dan Implementasi." Jakarta: Salemba Empat.

Eisenhardt, K. M. (1989). Agency Theory. Academy of Management Review, 14(1), pp.57-74.

https://doi.org/10.2307/258191

Emirzon, J. (2007). Prinsip-Prinsip Good Corporate Governance: Paradigma Baru dalam Praktik Bisnis di Indonesia. Yogyakarta: Genta Press.

Faccio, B. M., Larry, H., Lang, P., \& Young, L. (2001). Dividends and Expropriation. The American Economic Review, 91(1), 5478. https://doi.org/10.1257/aer.91.1.54

Fama, E.F. and Jensen, M. . (1983). "The cross section of expected stock returns". Journal of Finance, 47, 427-465.

Farinha, J. (2003). "Dividend policy, corporate governance and the managerial entrenchment hypothesis: an empirical analysis." Journal of Business Finance and Accounting, 30, 306-686.

Ghosh, S. (2006). Do board characteristics affect corporate performance? Firm-level evidence for India. Applied Economics Letters, 13(7), 435-443. https://doi.org/10.1080/135048505003 98617

Ghozali, Imam dan Ratmono, D. (2017). "Analisis Multivariat dan Ekonometrika: Teori, Konsep dan Aplikasi dengan EViews 10" (Kedua; B. P. U. Diponegoro, Ed.). Semarang.

Ginting, J. (2015). Pengaruh Good Corporate Governance Terhadap Kebijakan Dividen.

Gugler, K. and Yurtoglu, B. B. (2003). "Corporate governance and dividend pay-out policy in Germany". European Economic Review, 47, 731-758.

Gujarati, D. . (2013). Dasar-Dasar Ekonometrika (Edisi Keli). Jakarta: Salemba Empat.
Harada, K., \& Nguyen, P. (2011). Ownership concentration and dividend policy in Japan. Managerial Finance, 37(4), 362379.

https://doi.org/10.1108/030743511111 15313

He, T., Li, W.B. \& Tang, G. N. (2012). "Dividends behavior in state- versus family-controlled firms: evidence from Hong Kong." Journal of Business Ethics, 110, 97-112.

Heraclous, L. (2001). "What is the impact of corporate governance on organizational performance." Conference Papers, 9, 165173.

Horne, V. dan W. (2013). Prinsip-prinsip Manajemen Keuangan (Indonesia). Jakarta: Penerbit Salemba Empat.

Jabbouri, I. (2016). Determinants of corporate dividend policy in emerging markets: Evidence from MENA stock markets. Research in International Business and Finance, 37(May), 283-298. https://doi.org/10.1016/j.ribaf.2016.01. 018

Jensen, M. (1993). "The modern industrial revolution, exit and failure of internal control systems". Journal of Finance, 48, 831-880.

Jensen, M., \& Meckling, W. (1976). Theory of the firm: Managerial behaviour, agency costs and ownership. Strategic Management Journal, 21(4), 1215-1224. Retrieved from http://search.ebscohost.com/login.aspx ?direct $=$ true $\& \mathrm{db}=$ buh $\& \mathrm{AN}=12243301 \&$ site $=$ ehost-live

Jiraporn, P. and Ning, Y. (2006). "Dividend policy, shareholder rights, and corporate governance." Journal of Applied Finance, $16,24-36$.

Johnson, Simon, Rafael La Porta, Florencio Lopez-de-Silanes, and A. S. (2000). "Tunneling." American Economic Review Papers and Proceedings, 90, 22-27.

KNKG. (2006). "Pedoman Umum Good Corporate Governance Indonesia." 
Knyazeva, A. (2007). "'Delivering on the dividend promise: corporate governance, managerial incentives and dynamic dividend behavior."

Kowalewski, O., Stetsyuk, I. and Talavera, O. (2008). "'Does corporate governance determine dividend payouts in Poland?"' Post-Communist Economies, 20, 203-218.

Kumar, J. (2004). Ownership Structure and Dividend Payout Policy in India. Ssrn, 91(November). https://doi.org/10.2139/ssrn.474103

Laksmana, I. (2008). "Corporate board disclosure and voluntary disclosure of executive compensation practices." Contemporary Accounting Research, 25, 1147-1182.

Lam, K.C.K., Sami, H. and Zhou, H. (2012). "The role of cross-listing, foreign ownership and state ownership in dividend policy in an emerging market." China Journal of Accounting Research, 5, 199-216.

Leng, C. . (2008). "The impact of external and internal monitoring measures on firm's dividend payout: evidence from selected Malaysian listed companies". Corporate Ownership and Control, 5, 126-138.

Lipton, M. \& Lorsch, J. . (1992). "A modest proposal for improved corporate governance." Business Lawyer, 48, 59-77.

Livoreka, B., Hetemi, A., Shala, A., Hoti, A., \& Asllanaj, R. (2014). Theories on Dividend Policy Empirical Research in Joint Stock Companies in Kosovo. Procedia Economics and Finance, 14(14), 387-396.

https://doi.org/10.1016/s22125671(14)00727-8

Lucyanda, J., L. (2012). "Pengaruh Free Cash Flow Dan Struktur Kepemilikan terhadap Dividend Payout Ratio." Jurnal Dinamika Akuntansi, 4, 129-138.

Manos, R., Murinde, V. and Green, C. J. (2012). "Dividend policy and business groups: evidence from Indian firms." International Review of Economics \& Finance, 21, 42-56.

Maury, B. and Pajuste, A. (2005). "Multiple large shareholders and firm value."
Journal of Banking \& Finance, 29, 18131834.

Mili Mehdi, Jean-Michel Sahut, Frédéric Teulon, A. (2014). Do corporate governance and ownership structure impact dividend policy in emerging market during financial crisis? Journal of Applied Accounting Research.

Mitton, T. (2004). "Corporate governance and dividend policy in emerging markets." Emerging Markets Review, 5, 409-426.

Nachrowi, Djalal dan Usman, H. usman. (2006). "Pendekatan Populer dan Praktis Ekonometrika Untuk Analisis Ekonomi dan Keuangan." Jakarta: Lembaga Penerbit Fakultas Ekonomi Universitas Indonesia.

Nam, S.-W. and Nam, I. C. (2004). "Corporate governance in Asia: Recent Evidence from Indonesia, Republic of Korea, Malaysia and Thailand, Asian Development Bank Institute, Tokyo." Journal of Financial Economics.

Phalipu, H. (2005). "Fundamental Of Financial Management." Mc. Grae-Hill, Irwin.

PORTA, R. LA, LOPEZ-DE-SILANES, F., SHLEIFER, A., \& VISHNY, R. W. (2000). Fluid Phase Equilibria Effect of temperature and concentration of $\mathrm{H} 3 \mathrm{O}$ + ions on the intrinsic viscosity of poly ( ethylene oxide ) in aqueous solutions. Journal of Finance, 268(1), 109-113. https://doi.org/10.1016/j.fluid.2008.04. 004

Prabowo, M.A. and Simpson, J. (2011). "Independent directors and firm performance in family controlled firms: evidence from Indonesia." Asian-Pacific Economic Literature, 25, 121-132.

Rozeff, M. S. (1982). "Growth, Beta and Agency Costs as Determinants of Dividend Payout Ratios." Journal of Financial Research, 5, 249-259.

Sakir, A., \& Fadli, M. (2014). Influence of Managerial Ownership, Debt Policy, Profitability, Firm Size, and Free Cash Flow on Dividend Policy a Study in Indonesian Manufacturing Industries. Delhi Business Review $\square, 15(1), 15-22$. 
Sawicki, J. (2009). “'Corporate governance and dividend policy in Southeast Asia preand post-crisis."' The European Journal of Finance, 15, 211-230.

Setia-Atmaja, L. (2010). "Governance mechanism and firm value: the impact of ownership concentration and dividends." Corporate Governance: An International Review, 17, 694-709.

Setiawan, D., Bandi, B., Kee Phua, L., \& Trinugroho, I. (2016). Ownership structure and dividend policy in Indonesia. Journal of Asia Business Studies, 10(3), 230-252. https://doi.org/10.1108/JABS-05-20150053

Setiawan, D. dan L. K. P. (2013). Corporate governance and dividend policy in Indonesia. Managerial Finance, 39(6), 584-606. https://doi.org/10.1108/BSS01-2013-0003

Shleifer, A., \& Vishny, R. W. (2002). Large Shareholders and Corporate Control. Journal of Political Economy, 94(3, Part 1), 461-488. https://doi.org/10.1086/261385

Su, Z., Fung, H.-G., Huang, D. and Shen, C. H. (2013). "Cash dividends, expropriation, and political connections: evidence from China." International Review of Economics \& Finance, 46.

Sugiyono. (2013). "Metodelogi Penelitian Kuantitatif, Kualitatif Dan R\&D." Bandung: ALFABETA.

Sulong, Z., \& Ahmed, P. K. (2011). Ownership structure, board governance, dividends and firm value: an empirical examination of Malaysian listed firms. International Journal of Business Governance and Ethics, 6(2), 135. https://doi.org/10.1504/ijbge.2011.039 966

Taman, A. dan B. A. N. (2011). "DETERMINAN KUALITAS IMPLEMENTASI CORPORATE GOVERNANCE PADA PERUSAHAAN YANG TERDAFTAR DI BURSA EFEK INDONESIA (BEI) PERIODE 2004-2008." Journal of Finance.

Trinugroho, I., Agusman, A. and Tarazi, A. (2014). "Why have bank interest margins been so high in Indonesia since the 1997/1998 financial crisis?" Research in International Business and Finance, 32, 139158.

Vafeas, N. (1999). "Board meeting frequency and firm performance." Journal of Financial Economics, 53, 113-142.

Weston, J. F. dan Copeland, T. E. (1997). Manajemen Keuangan (Sembilan). Penerbit Bina Rupa Aksara.

Wijayanti, L. (2014). Terhadap Kebijakan Dividen Dan Struktur Modal Pada. Ekonomi Dan Bisnis, (1), 81-89.

Winarno, W. W. (2009). "Analisis Ekonometrika dan Statistika dengan EViews." Yogyakarta: Unit Penerbit dan Percetakan Sekolah Tinggi Ilmu Manajemen YKPN.

Xu'nan, F. (2011). "Dividends and tunneling: evidence from family firms in China." China Finance Review International, 1, 152167 